\title{
Determination of Nitrites in Water by In-electrode Coulometric Titration in Reticulated Vitreous Carbon Electrode
}

\author{
Katarina Lenghartova, ${ }^{1}$ Lukas Lauko, ${ }^{2}$ Frantisek Cachob $^{2}$ \\ and Ernest Beinrohr ${ }^{1,2, *}$ \\ ${ }^{1}$ Department of Chemistry, Faculty of Natural Sciences, University of SS. Cyril and Methodius in Trnava, J. Herdu 2 , \\ 91701 Trnava, Slovakia \\ ${ }^{2}$ Institute of Analytical Chemistry, Faculty of Chemical and Food Technology, Slovak University \\ of Technology in Bratislava, Radlinskeho 9, 81237 Bratislava, Slovakia \\ * Corresponding author: E-mail: ernest.beinrohr@stuba.sk
}

Received: 22-07-2014

\begin{abstract}
Nitrite in water samples was determined by in-electrode coulometric titration in a reticulated vitreous carbon (RVC) electrode of 100 ppi porosity. The sample was mixed with dilute sulphuric acid and sodium sulphate, aspirated into a flow cell with the porous electrode and nitrite was oxidised to nitrate by constant current of $5 \mu \mathrm{A}$ at which the potential of the electrode was monitored. The limits of detection and quantification were found to be 0.4 and $1.2 \mu \mathrm{g} / \mathrm{L}$, respectively. The repeatability and reproducibility were $2.2 \%$ and $2.6 \%$, respectively. The bias at $100 \mu \mathrm{g} / \mathrm{L}$ were found to be $0.3 \%$. The duration of the measurement is $2-3$ min depending on the nitrite concentration. There were a few interferents only, neutral and cationic surfactants decreased and increased slightly the signal, respectively. Humic acids above 30 $\mathrm{mg} / \mathrm{L}$ increased the signal by $10 \%$. Drinking and surface water samples were analysed and the results matched well those from the photometric method.
\end{abstract}

Keywords: Nitrite determination, drinking water, surface water, in-electrode coulometric titration, chronopotentiometry

\section{Introduction}

Nitrites in small amounts are natural components of the environment as a part of the nitrogen cycle. Higher amounts in soil and water are the result of enhanced application of nitrogen containing fertilisers. Sodium nitrite is used for curing of meat because it prevents bacterial growth and gives the product a desirable colour. Because of the relatively high toxicity of nitrite, the maximum allowed nitrite concentration in meat products is $200 \mathrm{mg} \mathrm{dm}^{-3}$. Nitrite in blood is highly reactive with haemoglobin and causes methaemoglobinaemia. Under certain conditions nitrites in meat can react with degradation products of amino acids, forming nitrosamines, which are known carcinogens. ${ }^{1}$

For the determination of nitrites various analytical methods are used such as volumetric analysis for higher levels, spectroscopic, electrochemical and separation methods for lower concentrations. ${ }^{2}$
Nitrite is mostly detected and analysed photometrically by making use of the Griess reaction, involving the formation of a deep red-coloured azo dye as the reaction product of $\mathrm{NO}_{2}^{-}$ions with sulfanilic acid and naphthyl-1amine in acidic media. ${ }^{3}$ These methods including also some other modified reagents enable the determination of nitrites at concentrations down to the low $\mu \mathrm{g} \mathrm{dm}^{-3}$ range.

Of electrochemical methods amperometry on glassy carbon electrode coated with gold ${ }^{4}$ or modified with complexes of $\mathrm{Fe}$ (III) and $\mathrm{Co}(\mathrm{II})^{5}$ was successfully used for nitrite determination water and orange juice samples. The detection limit was near $10 \mu \mathrm{g} \mathrm{dm}^{-3}$. Carbon black-modified electrodes were used for amperometric detection of nitrite and nitrate through oxidation of nitrite ${ }^{6}$. Nitrates were reduced first to nitrite and then measured.

Fogg and Alonso ${ }^{7}$ determined nitrites by differential pulse stripping voltammetry by making use of the adsorption of an azo dye formed by nitrate on hanging mercury 
drop electrode. The detection limit of the procedure for 5 min accumulation time was $7 \mathrm{ng} \mathrm{dm}^{-3}$. Chamsi and $\mathrm{Fogg}^{8}$ used an electrochemically pre-treated glassy carbon electrode in a flow system for nitrite detection through its direct electrochemical oxidation. Concentrations above $3 \mu \mathrm{g}$ $\mathrm{dm}^{-3}$ could be measured. The use of bare glassy carbon electrode was also demonstrated. ${ }^{9}$ Differential pulse voltammetric with gold ultramicroelectrode was used for nitrite sensing in natural waters..$^{10}$ The calculated detection limit was reported to be $30 \mu \mathrm{g} \mathrm{dm}^{-3}$. A cobalt film electrode on copper disk was reported for nitrite determination in water samples through their reduction in non-deaerated solutions ${ }^{11}$ with a detection limit about $10 \mu \mathrm{g} \mathrm{dm}^{-3}$.

Potentiostatic coulometry is a selective and accurate method for the determination of nitrite content in water samples through direct electrochemical oxidation to nitrate at a platinium electrode ${ }^{12}$. However, the method is more suitable for higher nitrite concentrations only. Contents down to $100 \mu \mathrm{g} \mathrm{dm}^{-3}$ can be determined by coulometric microdetermination via diazotization of 1-amino-4-naphthalenesulfonic acid ${ }^{13}$. He et al $^{14}$ determined nitrite by coulometric backtitration under flow conditions. Nitrite was reduced by hydrazine and the excess of hydrazine was coulometrically titrated by electrogenerated bromine. The detection limit was about $5 \mu \mathrm{g} \mathrm{dm}{ }^{-3}$.

Nitrites can be oxidised in porous electrodes as well which enables their determination by in-electrode coulometric titration (IECT). The method is in fact constant current chronopotentiometry in thin-layer arrangement which makes use of a constant current for direct electrochemical conversion of analyte species in the small pores inside the electrode bulk. The void volume of the electrode determines the volume of the sample being "titrated" by current. Unlike coulometric titrations in classical coulometric cells, the electrode here serves as a generator as well as the indicator electrode. Its potential follows the changes of the analyte concentration at the electrode surface. If the pore diameters are near or less than the diffusion layer thickness, the analyte concentration is virtually uniform in the pores. Hence, the potential is controlled by the analyte bulk concentration. In such a case, the sudden change of the potential in the instance when the analyte concentration at the electrode surface drops to zero (corresponding to the chronopotentiometric transition time) corresponds also to a virtually zero concentration in the bulk - it is actually the titration end point.

The paper presents a simple analytical procedure for nitrites by making use of their direct electrochemical oxidation in the RVC electrode.

\section{Materials and Methods}

\section{1. Instruments}

Flow-through chronopotentiometric measurements were carried out on a flow-through electrochemical analy- ser EcaFlow model GLP 150 (Istran, Ltd., Bratislava, Slovakia; internet address: www.istran.sk) equipped with two solenoid inert valves, a peristaltic pump and a microprocessor controlled potentiostat/galvanostat. The measured values of potential were treated by a $16-b i t 78 \mathrm{kHz}$ analog to digital converter. The block diagram and the operation mode of the system were given earlier. ${ }^{15}$ The signals were recorded and evaluated by the memory-mapping technique. ${ }^{16,17}$ In the resulting chronopotentiograms the content of the cannels (counts) in the channel counter were plotted against the potential values attributed to the particular channels. Hence, the chronopotentiometric signals were not obtained and displayed as a wave-like dependence of potential $v s$ time, but as a peak in the relation of counts $v s$ potential. Formally, the counts are expressed in $\mathrm{s} / \mathrm{V}$ units, but actually they are dimensionless numbers. Obviously, the integrated value of a peak $(A)$ is a dimensionless number as well for it is a sum of the content of channels between two potential values. The peak area is directly proportional to the chronopotentiometric transition time $(l)$ of the corresponding electrode process. The value of $\imath$ expressed in seconds can be obtained from the peak area by dividing it with the sampling frequency $f$ of the analog to digital converter of the instrument: $\imath=\mathrm{A} / \mathrm{f}$.

The measurement consisted of two main steps: i) the background signal was measured first by means of the blank sample, ii) then, the sample or standard solution was measured. The background signal was subtracted from this signal yielding a true background corrected net signal. The operation parameters are listed in Table $\mathbf{1}$.

Table 1: Operation parameters of the flow-through analyser

\begin{tabular}{|c|c|c|}
\hline Parameter & Dimension & Value \\
\hline Aspirating potential & $\mathrm{mV}$ & 0 \\
\hline Quiescence potential & $\mathrm{mV}$ & 600 \\
\hline Quiescence time & $\mathrm{s}$ & 5 \\
\hline Terminal potential & $\mathrm{mV}$ & 1100 \\
\hline Standby potential & $\mathrm{mV}$ & 0 \\
\hline Oxidation current & $\mu \mathrm{A}$ & 5 \\
\hline Sample volume & $\mathrm{mL}$ & 4 \\
\hline Flow rate & $\mathrm{mL} \min ^{-1}$ & 3 \\
\hline
\end{tabular}

Compact flow-through electrochemical cells of type 104 with Pt auxiliary and built-in $\mathrm{Ag} / \mathrm{AgCl}$ reference electrodes was employed. As working electrodes the macroporous E-104 electrode was used (all from Istran, Ltd., Bratislava, Slovakia). The electrode E-104 was fabricated from a reticulated vitreous carbon plug of 100 ppi (pores per inch) porosity (Electrosynthesis Co. Inc., Lancaster, New York, USA) with $10 \mathrm{~mm}$ and $4 \mathrm{~mm}$ in diameter and length, respectively (Fig. 1). Its effective volume and active surface area were $300 \mu \mathrm{L}$ and $17 \mathrm{~cm}^{2}$, respectively. The pores were almost regular with diameters of about $500 \mu \mathrm{m}$.

For the determination of the electrode reaction stoichiometry the E-56 electrode was used (Istran, Ltd., Brati- 
slava, Slovakia). It was made of a carbon cylinder (height $6 \mathrm{~mm}$, inner and outer diameter $5 \mathrm{~mm}$ and $10 \mathrm{~mm}$, resp.). The cylinder was filled with crushed reticulated vitreous carbon material and closed from both sides with porous frits. The effective volume and active surface area of the electrode were approximately $35 \mu \mathrm{L}$ and $45 \mathrm{~cm}^{2}$, respectively. The pores in the electrode were irregular with diameters of 5 to $20 \mu \mathrm{m}$.

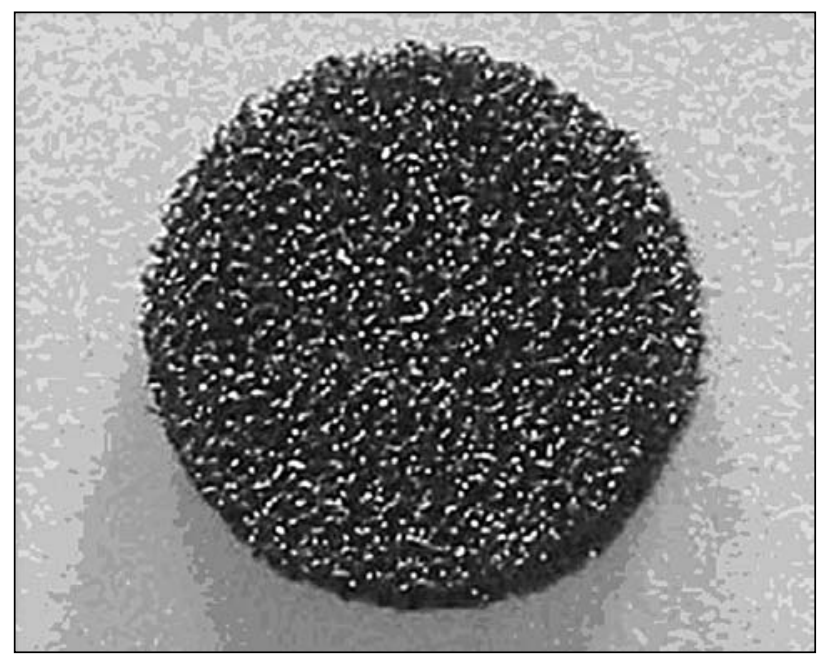

Figure 1: RVC electrode

The potentials throughout this paper are expressed against the $\mathrm{Ag} / \mathrm{AgCl}$ reference electrode.

The accuracy of the results was checked by spectrophotometry on a Varian Cary 50 Bio UV-visible spectrophotometer.

\section{2. Reagents and Solutions}

CRM for nitrite: $1.000 \pm 0,002 \mathrm{~g} \mathrm{dm}^{-3}, \mathrm{CRM} \mathrm{CZ}$ 9075(1H), Czech Metrological Institute, Prague, Czech Republic.

Carrier electrolyte for IECT: $0.1 \mathrm{~mol} \mathrm{dm}^{-3} \mathrm{Na}_{2} \mathrm{SO}_{4}$; $0.01 \mathrm{~mol} \mathrm{dm}^{-3} \mathrm{CH}_{3} \mathrm{COONa} ; 0.01 \mathrm{~mol} \mathrm{dm}{ }^{-3} \mathrm{CH}_{3} \mathrm{COOH}$.

Reagent for sample adjustment in IECT: $1.0 \mathrm{~mol}$ $\mathrm{dm}^{-3} \mathrm{Na}_{2} \mathrm{SO}_{4}, 0.05 \mathrm{~mol} \mathrm{dm}^{-3} \mathrm{H}_{2} \mathrm{SO}_{4}$

Colour reagent for nitrite ${ }^{18}: 4 \mathrm{~g}$ of 4 -aminobenzene1 -sulfonamid is dissolved in a mixture of $10 \mathrm{~mL} 15 \mathrm{~mol}$ $\mathrm{dm}^{-3} \mathrm{H}_{3} \mathrm{PO}_{4}$ and $50 \mathrm{~mL}$ water. On dissolving $0.2 \mathrm{~g}$ of dihydrochlorid $\mathrm{N}$-(1-naftyl)-1,2-diaminoethane the volume of the solution is adjusted to $100 \mathrm{~mL}$ with water. At $2-5{ }^{\circ} \mathrm{C}$ the reagent is stable over a month.

\section{3. Procedures}

Sample treatment: The samples were stored at $5 \mathrm{C}^{\circ}$. Prior to analysis the samples were filtered and in the case of high hydrocarbonate contents were boiled.
IECT: The sulphuric acid and sodium sulphate solution was added to the sample to a final concentration of $0.1 \mathrm{~mol} \mathrm{dm}^{-3}$ and $0.005 \mathrm{~mol} \mathrm{dm}{ }^{-3}$ in $\mathrm{Na}_{2} \mathrm{SO}_{4}$ and $\mathrm{H}_{2} \mathrm{SO}_{4}$, respectively. Alkaline samples were neutralised with diluted sulphuric acid first.

Photometry: To $40 \mathrm{~mL}$ sample $1 \mathrm{~mL}$ of the colour reagent was added, the volume was adjusted to $50 \mathrm{~mL}$ with water and the solution was stirred up. On $20 \mathrm{~min}$ the absorbance was measured at $540 \mathrm{~nm}$. The blank sample was prepared and measured in the same way just water was taken instead of the sample.

\section{Results and Discussion}

Porous flow-through electrodes exhibit several special features, the main important ones being the large electrode surface to volume ratio and the thin layer character. The former property ensures high electrochemical conversions the latter facilitates direct coulometric titrations inside the electrode bulk.

The surface to volume ratio is decisive for applications where high recoveries of the electrolysis are requested, e.g. for metal removal in waste water treatment ${ }^{19-21}$ or electrochemical pre-concentration for atomic spectroscopy. ${ }^{22}$ Obviously, the electrochemical properties such as electrochemical signal to background ratio are of no significance here. On the contrary, by making use of the thin-layer character of porous electrodes, e.g. in in-electrode coulometric titrations (IECT), the signal to background ratio is of high importance for it influences the detection limit of the method which is decisive when trace concentrations are to be determined. The signal to background ratio is inversely proportional to the surface to volume ratio and this fact limits the geometrical arrangement of porous electrodes, especially the pore size.

\section{1. Stoichiometry of the Electrode Reaction}

The stoichiometry of the electrode reaction was determined by making use of the E-56 electrode which enables a complete and fast electrolysis of the analyte in the pores of the electrode. ${ }^{23}$ The pore diameters $(5-20 \mu \mathrm{m})$ are within the diffusion layer thickness and the electrode reaction is no more diffusion controlled. Hence, differences in diffusion constants do not affect the rate of electrolysis.

The chronopotentiometric transition time $l$ can be expressed by means of the Faraday laws of electrolysis as follows:

$$
\mathrm{l}=\mathrm{zF} \mathrm{c} \mathrm{V}_{\text {eff }} / \mathrm{I}
$$

where $z$ denotes the charge number of the electrode process, $F$ the Faraday constant in $\mathrm{C} \mathrm{mol}^{-1}, c$ analyte concen- 
tration in mol dm${ }^{-3}, V_{\text {eff }}$ the effective void volume of the porous electrode in $\mathrm{dm}^{3}$, and $I$ the applied current in A.

The effective void volume of the electrode can be obtained by analysing solutions of known concentrations of species and with known stoichiometry of the electrode process. Potassium ferrocyanide in $\mathrm{KCl}$ solutions was used to find out the electrode volume by making use of $\mathrm{Eq}$ (1). The volume $V_{\text {eff }}$ was found to be $36.1 \pm 0.6 \mu \mathrm{L}$. By analysing solutions with known nitrite concentrations and taking this volume, Eq (1) resulted a charge number of $2.01 \pm 0.05$ which implies the following equation for the electrode reaction:

$$
\mathrm{NO}_{2}^{-}+\mathrm{H}_{2} \mathrm{O}-2 \mathrm{e}^{-} \rightarrow \mathrm{NO}_{3}^{-}+2 \mathrm{H}^{+}
$$

\section{2. Optimisation of Experimental Parameters}

As Eq (2) implies, the oxidation potential of nitrites is $\mathrm{pH}$ dependent, by decreasing the $\mathrm{pH}$ value the potential is shifted to more positive values and vice versa. At $\mathrm{pH}$ values below 1 the nitrite ions decompose rapidly and the results are less reproducible. Moreover, in such solutions the oxidation peak is shifted to potentials where the background signal may obscure the signal of nitrite, especially in the presence of chloride ions which are oxidised to chlorine.

In less acidic and neutral solutions the oxidation peak is shifted to more negative values and is well separated from the background signal up to $\mathrm{pH}$ values of $8-9$ (Fig. 2). In more alkaline solutions there is a competitive electrode reaction, namely the oxidation of hydroxide ions:

$$
4 \mathrm{OH}^{-}-4 \mathrm{e}^{-} \rightarrow \mathrm{O}_{2}+2 \mathrm{H}_{2} \mathrm{O}
$$

Like the nitrite oxidation this reaction is $\mathrm{pH}$ dependent, the oxidation peak is shifted to more negative values when increasing the $\mathrm{pH}$ value. Above $\mathrm{pH} 8$ the background caused by this oxidation is enhancing considerably and the signal evaluation is no more reliable or even possible (Fig. 2)

Owing to the low currents used for the oxidation, the ionic strength of the solution had a small influence on the peak position and width only. Acidic solutions yielded more reproducible signals than neutral and slightly alkaline ones, so the testing and sample solutions were adjusted to contain $0.1 \mathrm{~mol} \mathrm{dm}^{-3}$ and $0.005 \mathrm{~mol} \mathrm{dm}^{-3}$ in $\mathrm{Na}_{2} \mathrm{SO}_{4}$ and $\mathrm{H}_{2} \mathrm{SO}_{4}$, respectively.

In porous electrodes with pore sizes significantly larger than the diffusion layer thickness the response (chronopotentiometric transition time) obeys more the Sand equation than Eq (1), i.e. the concentration dependence is no more linear, especially at higher current densities. To retain linearity, the current densities should be as low as possible. However, very low current densities may induce undesirable effects, namely i) a significant portion of the applied current may be consumed by non-faradayic processes such as double layer charging and electrode material reactions, ii) the duration of the electrolysis may become unacceptably long. Hence, compromised conditions should be found at which the linearity and reasonable measurement times can be assured.

Currents below $3 \mu \mathrm{A}$ prolonged the measurement up to $10 \mathrm{~min}$ and more. Over $20 \mu \mathrm{A}$ the measurement was significantly faster but there was a considerable non-linearity of the response, especially at the lower concentration range (below $10 \mu \mathrm{g} \mathrm{dm}^{-3}$ ). Oxidation current of $5 \mu \mathrm{A}$ was found to generate sufficiently linear response and measurement times of 3-10 min.

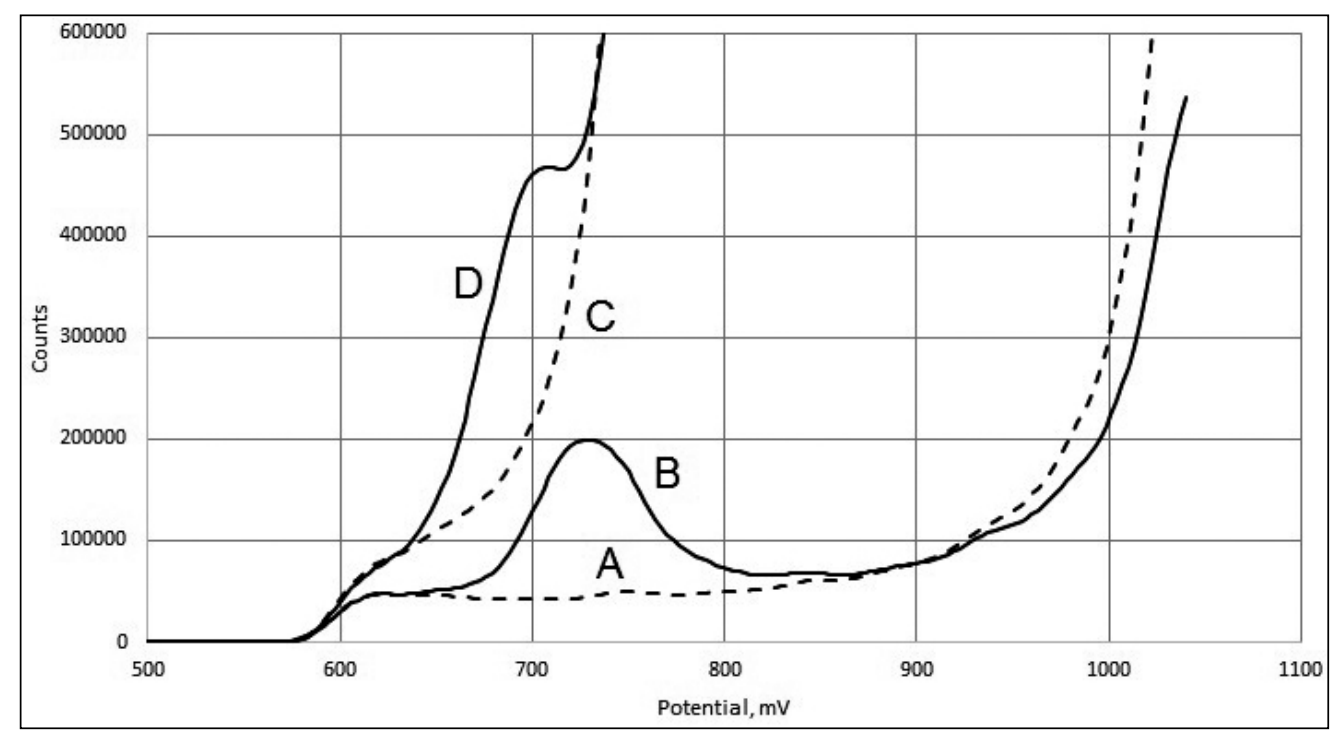

Figure 2: Chronopotentiograms of the blank and $1.0 \mathrm{mg} \mathrm{dm}^{-3}$ nitrite at $\mathrm{pH} 2.6$ (curves A and B) and $\mathrm{pH} 9.1$ (curves C and D), respectively. 


\section{3. Interferences}

The influence of various species common in water samples was investigated in concentration ranges which are typical for underground, surface, drinking and mineral waters (Table 2).

Hydrocarbonate over $400 \mathrm{mg} \mathrm{dm}^{-3}$ interferes owing to changes of $\mathrm{pH}$ value and release of carbon dioxide which forms bubbles in the solution and electrode. Such samples should be boiled prior to the analysis to remove hydrocarbonate. This step does not affect the nitrite content and the subsequent measurement.

The anionic surfactant does not influence the nitrite signal. There is a slight increase of the signal at concentrations above $10 \mathrm{mg} \mathrm{dm}^{-3}$ of the cationic surfactant, at 20 $\mathrm{mg} \mathrm{dm}{ }^{-3}$ the signal is $10 \%$ higher than without the surfactant. The neutral surfactant decreases the signal, at 20 and $100 \mathrm{mg} \mathrm{dm}^{-3}$ there is a $4 \%$ and $20 \%$ decrease, respectively. Humic acids at concentrations above $20-30 \mathrm{mg} \mathrm{dm}^{-3}$ slightly increase the signal. Surprisingly, Fe(II) ions in- creased the signal at concentrations above $0.5 \mathrm{mg} \mathrm{dm}^{-3}$ only, i.e. they were actually not oxidised to Fe(III) under the applied parameter setting and $\mathrm{pH}$. The remaining species did not exert any influence on the results.

\section{4. Analytical Figures of Merit}

The overall performance of the elaborated procedure was tested by analyses of model samples. The results are summarised in Table 3. The values of limit of detection (LOD) and limit of quantitation (LOQ) were calculated by making use of the upper limit approach. ${ }^{24}$ The repeatability of the results $s_{r}$ was determined by performing 10 analyses of the same solution in a fast sequence and is expressed as the relative standard deviation of the results. The reproducibility $s_{r}$, was determined by analysing fresh solutions with the same nitrite content but during a 10 days period of time. The bias $e$ gives the absolute value of the difference between the obtained results and the nominal or reference concentration relative to the reference va-

Table 2: Tested species for interference study

\begin{tabular}{|c|c|c|c|}
\hline Tested species & Added as & $\begin{array}{l}\text { Tested range, } \\
\mathrm{mg} \mathrm{dm}^{-3}\end{array}$ & $\begin{array}{c}\text { Interfering } \\
\text { concentration }^{\mathrm{a}}, \mathrm{mg} \mathrm{dm}^{-3}\end{array}$ \\
\hline$\overline{\mathrm{Fe}^{2+}}$ & $\mathrm{FeSO}_{4} \cdot 7 \mathrm{H}_{2} \mathrm{O}$ & $0.1-1$ & $0.8(+)$ \\
\hline $\mathrm{Ca}^{2+}$ & $\mathrm{CaSO}_{4} \cdot 2 \mathrm{H}_{2} \mathrm{O}$ & $100-400$ & none \\
\hline $\mathrm{Mg}^{2+}$ & $\mathrm{MgSO}_{4} \cdot 7 \mathrm{H}_{2} \mathrm{O}$ & $100-400$ & none \\
\hline $\mathrm{NH}_{4}^{+}$ & $\left(\mathrm{NH}_{4}\right)_{2} \mathrm{SO}_{4}$ & $20-200$ & none \\
\hline $\mathrm{Cl}^{-}$ & $\mathrm{NaCl}$ & $20-2000$ & none \\
\hline $\mathrm{HCO}_{3}^{-}$ & $\mathrm{NaHCO}_{3}$ & $100-1000$ & $400(-)$ \\
\hline $\mathrm{NO}_{3}^{-}$ & $\mathrm{NaNO}_{3}$ & $50-300$ & none \\
\hline Anionic surfactant & SDS & $10-500$ & none \\
\hline Neutral surfactant & Tween 80 & $10-100$ & $60(-)$ \\
\hline Cationic surfactant & TBAB & $8-20$ & $10(+)$ \\
\hline Humic substance & Sodium humate & $5-50$ & $30(+)$ \\
\hline
\end{tabular}

SDS: sodium dodecylsulphate, Tween 80 : polysorbate 80 , TBAB: tetrabutyl ammonium bromide; Nitrite concentration: $100 \mu \mathrm{g} \mathrm{dm}^{-3}$

${ }^{\text {a }}$ Concentration of the tested species causing a $10 \%$ increase $(+)$ or decrease $(-)$ of the signal

Table 3: Analytical figures of merit

\begin{tabular}{lcccc}
\hline Parameter & Symbol & $\begin{array}{c}\text { Obtained at } \\
\text { concentration, }{\mathbf{~} \mathbf{~ d m}^{-\mathbf{3}}}^{-3}\end{array}$ & Dimension & Value \\
\hline Limit of detection & $\mathrm{LOD}$ & - & $\mu \mathrm{g} \mathrm{dm}^{-3}$ & 0.4 \\
Limit of quantitation & $\mathrm{LOQ}$ & - & $\mu \mathrm{g} \mathrm{dm}^{-3}$ & 1.3 \\
Repeatability & $\mathrm{s}_{\mathrm{r}}$ & 100 & $\%$ & 2.2 \\
Reproducibility & $\mathrm{s}_{\mathrm{r}}$ & 100 & $\%$ & 2.6 \\
Bias & $\mathrm{e}$ & 100 & $\%$ & 0.3 \\
Accuracy & $\mathrm{R}_{\mathrm{e}}$ & 100 & $\mu \mathrm{g} \mathrm{dm}^{-3}$ & $1.3-1000$ \\
Range & - & - & 1 & 0.9997 \\
Linearity & $\mathrm{R}^{*}$ & - & $\mathrm{min}$ & $2-3$ \\
Measurement duration & & - & & \\
\hline
\end{tabular}

* R: regression coefficient of the concentration dependence $\mathrm{l}=0.1530119 \rho$, where $\mathrm{l}$ is the signal (transition time) in seconds and $\rho$ is the nitrite concentration in $\mu \mathrm{g} \mathrm{dm}^{-3}$. Regression data valid for the $0-20 \mu \mathrm{g}$ $\mathrm{dm}^{-3}$ concentration range. 
lue. The accuracy $R_{e}$ refers to the ratio of the obtained value to the reference one (method recovery). The analytical range refers to the concentration range limited from the lower and upper end by the LOQ and the highest linear response, respectively. Measure of linearity is the regression coefficient $R$ of the concentration dependence.

These data imply that all criteria of a sound analytical performance are fulfilled and the method has the capacity to deliver reliable results in a broad concentration of nitrites.

The performance of the elaborated procedure was tested with analyses of real samples.

\section{5. Real Samples}

Various water samples were collected and analysed by the elaborated method (Table 4). The accuracy was checked by analysing spiked samples and by means of spectrophotometric measurements.

The spike recoveries were found to be in the range of $81-116 \%$. Except for two samples a satisfactory match was found between the electrochemical and photometric methods as well. For the flavoured soft drink sample (Table 4) the chronopotentiometric method delivered an overestimated value, though the spike recovery was normal. The probable reason was the colour additive to the sample which interfered through its electrochemical oxidation and enhanced the chronopotentiometric signal.

\section{Conclusions}

The determination of nitrites through their direct electrochemical oxidation in porous electrodes (in-electrode coulometric titration) was found to be a simple and fast way of analysis of water samples for nitrites. In most cases, the sample requires the addition of a solution containing dilute sulphuric acid and sodium sulphate only which is a significant advantage over the commonly used photometric methods which make use of toxic organic reagents. There are few interferents in samples commonly analysed. The interfering effect of high carbonate content can be eliminated though boiling the sample prior to analysis. The porous electrode is cheap and its lifetime is over several hundreds of analyses which make the running costs extremely low. Owing to the satisfactory performance, simplicity, speed and low running costs is the method suitable for routine use and in applications in water monitoring devices.

\section{Acknowledgements}

This publication was supported by the Competence Center for SMART Technologies for Electronics and Informatics Systems and Services, ITMS 26240220072, and by the Slovak Grant Agency VEGA (project No. 1/0419/12). F. C. and E. B. appreciate the financial support of the grant agency APVV (project No. APVV-0797$11)$.

\section{References}

1. P. Jakszyn, C. A. Gonzalez, World J. Gastroenterol., 2006, 12, 4296-4303.

2. T. R. Crompton, Determination of Anions, Springer, Berlin, 1996.

http://dx.doi.org/10.1007/978-3-642-61419-4

3. V. M. Ivanov, J. Anal. Chem., 2004, 59, 1002-1005. http://dx.doi.org/10.1023/B:JANC.0000043920.77446.d7

4. Y. Liu, H.-Y. Gu, Microchim. Acta, 2008, 162, 01-106.

5. W. J. R. Santos, A.L. Sousa, R. C. S. Luz, F. S. Damos, L. T. Kubota, A. A. Tanaka, S. M. C. N. Tanaka, Talanta, 2005, 70, 588-594.

http://dx.doi.org/10.1016/j.talanta.2006.01.023

6. S. Islam, R. Malha, J. Mandli, A. Ourari, A. Amine, Electroanalysis, 2013, 25, 2289-2297.

7. A. G. Fogg, R. M. Alonso, Analyst, 1988, 113, 1337-1338. http://dx.doi.org/10.1039/an9881301337

8. A. Y. Chamsi, A. G. Fogg, Analyst, 1988, 113, 1723-1727. http://dx.doi.org/10.1039/an9881301723

9. B. R. Kozub, N. V. Rees, R. G. Compton, Sensor. Actuator. B-Chem., 2010, 143, 539-546.

Table 4: Nitrite in underground, drinking and surface water samples

\begin{tabular}{|c|c|c|c|c|c|}
\hline Sample & $\begin{array}{c}\text { IECT } \\
\mu \mathrm{g} \mathrm{dm}^{-3}\end{array}$ & $\begin{array}{c}\text { Photometry } \\
\mu \mathrm{g} \mathrm{dm}^{-3}\end{array}$ & $\begin{array}{c}\text { Spike } \\
\text { recovery } \%\end{array}$ & $\underset{\%}{\text { Accuracy }}$ & $\begin{array}{c}\text { Range of found } \\
\text { concentrations } \mu \mathrm{g} \mathrm{dm}-3\end{array}$ \\
\hline 1 & $21.6 \pm 0.9$ & $21.7 \pm 0.1$ & 112 & 99 & $3.0-21.6$ \\
\hline 2 & $0.50 \pm 0.05$ & $0.52 \pm 0.04$ & 85 & 96 & $0.4-1.4$ \\
\hline 3 & $1.2 \pm 0.2$ & $1.37 \pm 0.04$ & 109 & 88 & $1.2-3.3$ \\
\hline 4 & $3.11 \pm 0.07$ & $1.94 \pm 0.04$ & 98 & 160 & \\
\hline 5 & $46.1 \pm 2.9$ & $46.3 \pm 0.5$ & 105 & 98 & $46-146$ \\
\hline 6 & $131 \pm 1$ & $130.5 \pm 1.0$ & 105 & 101 & $17-131$ \\
\hline
\end{tabular}

1: underground water; 2: drinking water; 3: natural mineral water carbonated; 4: soft drink orange flavoured, slightly carbonated; 5: creek and river water; 6: lake 
10. S, Maria da Silva, L. H. Mazo, Electroanalysis, 1998, 10, 1200-1203.

11. K. Soropogui, M. Sigaud, O. Vittori, Electroanalysis, 2007, 19, 2559-2564. http://dx.doi.org/10.1002/elan.200704008

12. J. E. Harrar, Anal. Chem., 1971, 43, 143-145. http://dx.doi.org/10.1021/ac60296a027

13. S. T. Sulaiman, I. J. Al-Nuri, Microchem. J., 1986, 33, 112115. http://dx.doi.org/10.1016/0026-265X(86)90087-1

14. Z. K. He, B. Fuhrmann, U. Spohn, Fresenius J. Anal. Chem., 2000, 367, 264-269. http://dx.doi.org/10.1007/s002160000325

15. E. Beinrohr, M. Cakrt, J. Dzurov, L. Jurica, J. A. C. Broekaert, Electroanalysis, 1999, 11, 1137-1144. http://dx.doi.org/10.1002/(SICI)1521-4109(199911)11:15< 1137::AID-ELAN1137>3.0.CO;2-Z

16. K. N. Thomsen, H. J. Skov, M. E. R. Dam, Anal. Chim. Acta, 1994, 293, 1-17. http://dx.doi.org/10.1016/0003-2670(94)00078-6

17. A. Hu, R. E. Dessy, A. Graneli, Anal. Chem. 1983, 55, $320-328$. http://dx.doi.org/10.1021/ac00253a031

18. STN EN 26777 (75 7438). Kvalita vody. Stanovenie dusitanov. Molekulárna absorpčná spektrofotometrická metóda. (Water quality. Determination of nitrites. Molecular absorption spectrophotometric method). 1998.

19. C. Lestrade, P. Y. Guyomar, M. Astruc, Environ. Technol. Lett., 1981, 2, 409-418. http://dx.doi.org/10.1080/09593338109384070

20. R. Bertazzoli, R. C. Widner, M. R. V. Lanza, R. A. Di Iglia, M. F. B. Sousa, J. Braz. Chem. Soc., 1997, 8, 487-493. http://dx.doi.org/10.1590/S0103-50531997000500009

21. J. M. Friedrich, C. Ponce-de-Leon, G. W. Reade, F. C. Walsh, J. Electroanal. Chem., 2004, 561, 203-217. http://dx.doi.org/10.1016/j.jelechem.2003.07.019

22. E. Beinrohr, Mikrochim. Acta, 1995, 120, 39-52. http://dx.doi.org/10.1007/BF01244418

23. E. Beinrohr, Accred. Qual. Assur., 2001, 6, 321-324. http://dx.doi.org/10.1007/s007690000269

24. J. Mocak, A. M. Bond, S. Mitchell, G. Scollary, Pure Appl. Chem., 1997, 69, 297-328.

http://dx.doi.org/10.1351/pac199769020297

\section{Povzetek}

Nitrit smo določali v vodnih vzorcih z znotraj-elektrodno kulometrično titracijo v elektrodi iz mrežastega steklastega ogljika (RVC) s poroznostjo 100 ppi. Vzorcu smo dodali razredčeno žveplovo kislino in natrijev sulfat ter ga posesali v pretočno celico s porozno elektrodo. Nitrit se je oksidiral do nitrata pri konstantnem toku $5 \mu \mathrm{A}$, pri čemer smo spremljali potencial elektrode. Meja zaznave je bila $0,4 \mu \mathrm{g} / \mathrm{L}$, meja določitve pa $1,2 \mu \mathrm{g} / \mathrm{L}$. Ponovljivost je bila $2,2 \%$, obnovljivost pa 2,6\%. Odstopanje pri $100 \mu \mathrm{g} / \mathrm{L}$ je bilo $0,3 \%$. Meritev je trajala 2-3 min, odvisno od koncentracije nitrita. Ugotovili smo le nekaj interferentov: nevtralni surfaktanti so rahlo znižali signal, kationski pa so ga rahlo zvišali. Huminske kisline nad $30 \mathrm{mg} / \mathrm{L}$ so zvišale signal za $10 \%$. Analizirali smo vzorce pitne in površinske vode, rezultati so se dobro ujemali z rezultati fotometrične metode. 